\title{
Ervaringsleren in verpleeghuiszorgorganisaties
}

\section{Resultaten van een 24-uurs-event en organisatiespecifiek vervolg}

\author{
Arjella R. van Scheppingen - Johan J. Visser · Paulien den Bode · Betsy van de Camp
}

Published online: 30 October 2019

(c) The Author(s) 2019

Samenvatting Verpleeghuiszorgorganisaties ontwikkelen in toenemende mate naar meer persoonsgerichte zorg. Van zorgprofessionals wordt daarom 'individuele professionaliteit' verwacht: zelfleiderschap voor het bieden van zorg die op dat moment voor die persoon nodig is, en dat in open samenwerking met anderen. Veranderingen die diep ingrijpen op intermenselijk niveau vereisen diepgaande leerprocessen. Ervaringsleren lijkt hierin veelbelovend, maar er is vooralsnog weinig kennis over de effecten ervan in de praktijk. Ook ontbreekt het aan routines om deze vorm van leren te verankeren in de verpleeghuiszorgorganisaties. Dit onderzoek laat de bevindingen zien van een ervaringsgerichte benaderingswijze, 'de ParticipatieKliniek' (PK), in 21 verpleeghuiszorgorganisaties. De kern van de aanpak is een 24-uurs-event waarin zorgprofessionals een rolwisseling als cliënt ervaren. In vijf van deze organisaties vond aansluitend een organisatiespecifiek vervolg plaats (PK-in-Huis). Voor een gemotiveerde groep zorgprofessionals draagt deze ervaringsgerichte benaderingswijze bij aan persoonsgerichtere manieren van (samen)werken. Een organisatiespecifiek vervolg zet aan tot 'dieper' leren en stimuleert veranderingen in de organisatie waar de betrokkenen samen de schouders onder zetten. Voor het bevorderen van zelfbeschikking onder zorgprofessionals en sociaal organisatiekapitaal zijn ervaringsge-

Dr. A. R. van Scheppingen $(\triangle)$

Amsterdam, Nederland

Arjella.vanscheppingen@gmail.com

J. J. Visser

Principle care, Nijmegen, Nederland

P. den Bode

V\&VN, Utrecht, Nederland

B. van de Camp

Zorggroep Elde, Boxtel, Nederland richte events alleen niet voldoende. Daarvoor is een gezamenlijk leerproces relevanter, met actieve betrokkenheid van de diverse belanghebbenden, aansluiting tussen verschillende initiatieven en perspectieven, en een gezamenlijke betekenisgeving aan ervaringsleren.

Trefwoorden ervaringsleren - collectief leren · persoonsgerichte ouderenzorg · zelfbeschikking · sociaal organisatiekapitaal

\section{Experience-based learning in nursing homecare organisations \\ Results of a 24-hour event and an organization- specific follow-up}

Abstract Nursing homecare organisations develop towards more person-oriented care. To this end, healthcare professionals are expected to show individual professionalism': self-direction to provide care that is required for every person, in collaboration with others. Changes that so much intervene at an interpersonal level require in-depth learning. Experiencebased learning seems promising, but little is known about its effects in practice. There is also a lack of routines to anchor this form of learning in organisations. This research shows the findings of an experience-based approach, 'The Participation Clinic', in 21 nursing homecare organisations. The core of the approach is a 24-hour event in which healthcare professionals experience a role change as a client. Subsequently, an organization-specific follow-up took place in 5 of these organisations. For a motivated group of healthcare professionals, this experience-based approach contributes to more person-oriented ways of working. An organisation-specific follow-up encourages 'deeper' learning and encourages changes in the organisation that people support. Experience-based events on their own do not seem to be enough to 
stimulate self-determination and organisational social capital. A learning process with active involvement of stakeholders, alignment between various initiatives and perspectives within the organisation and a shared meaning towards experience-based learning seem more relevant for this.

Keywords experience-based learning · collective learning · person-oriented care - self-determination · organisational social capital

\section{Inleiding}

De ouderenzorg verandert. Zorgorganisaties maken de slag naar persoonsgerichte zorg, waarin eigen regie en menselijke waardigheid vooropstaan. Cliënten mogen goede zorg verwachten, maar zich ook gekend voelen om zo veel mogelijk hun eigen leven te blijven leiden [1]. Dat betekent voor professionals dat ze de zorg moeten afstemmen op de cliënt en daar, samen met anderen, invulling aan geven. Het vergt nogal een omslag in de door protocollen gedomineerde zorg. Elke persoon en ieders persoonlijke context zijn immers anders. Meer dan voorheen wordt een beroep gedaan op de relationele vaardigheden van zorgprofessionals [2]. Gevraagd wordt om 'reflectieve professionals', om 'individuele professionaliteit' en om 'zelfleiderschap' [3-5]. Professionals worden geacht zelf weloverwogen keuzen te maken om te doen wat nodig is voor elke cliënt, en dat in verbinding met anderen invulling te geven.

Een theorie die hierop aansluit en er onderbouwing voor geeft is de zelfbeschikkingstheorie [6]. Deze theorie gaat uit van drie psychologische basisbehoeften (autonomie, competenties en verbondenheid) die, mits eraan voldaan wordt, zelfbeschikking van mensen stimuleren. Volgens deze theorie ontwikkelen zorgprofessionals zich tot de gewenste zelfsturende, reflectieve professionals als zij autonomie ervaren, zich competent voelen en verbondenheid ervaren met anderen. Voor werksituaties geldt dat deze basisbehoefte aan verbondenheid sterk verwant is met het sociaal organisatiekapitaal: een werkklimaat waarin mensen in openheid en onderling vertrouwen samenwerken [7].

Veranderingen die sterk ingrijpen op intermenselijk niveau kunnen niet worden opgelegd of voorgeschreven, maar vragen om collectief en 'dieper' leren $[8,9]$. Dieper leren is betekenisvol leren. Nieuwe inzichten worden geïntegreerd in bestaande kennis en vaardigheden [10]. Het gaat om reflecteren en leren in samenspraak met anderen. Het leidt tot 'tweedeordeleereffecten' (of hogere-ordeleereffecten), waarin gezamenlijke ervaringskennis wordt bijgesteld op basis van gedeelde inzichten. Deze diepere vorm van leren onderscheidt zich van 'eerste orde leren', waarbij het gaat om het verbeteren van het eigen handelen, de dingen beter doen [11]. In arbeidsorganisaties blij- ken diepere vormen van leren nodig om te komen tot vernieuwing [12].

Ervaringsleren lijkt een relevante manier om dit dieper leren te stimuleren. Zo toont onderzoek onder zorgprofessionals (in opleiding) aan dat het ervaren van een rolwisseling als cliënt bijdraagt aan persoonlijke reflectie, ethische reflectie en empathisch vermogen [13-15]. Ervaringsleren wordt in verband gebracht met de morele vorming van zorgprofessionals en is voor zorgprofessionals een aansprekende leerstrategie gebleken [16, 17]. Over de effecten van ervaringsleren op het persoonsgerichte handelen van zorgprofessionals in de praktijk zijn echter nog weinig empirische gegevens bekend. Ook is het nog niet zo gebruikelijk om vormen van ervaringsleren te integreren en te verankeren in zorgorganisaties.

Dit artikel beoogt bij te dragen aan de ontwikkeling van kennis over de effecten van ervaringsleren in de verpleeghuiszorg. Ook wil het inzicht geven in de wijze waarop ervaringsleren kan worden verankerd in zorgorganisaties en wat daarvan de toegevoegde waarde is. De bevindingen zijn gebaseerd op de ervaringsgerichte benaderingswijze 'de ParticipatieKliniek', een initiatief van de beroepsvereniging voor verzorgenden en verpleegkundigen $(\mathrm{V} \& \mathrm{VN})$, uitgevoerd door Stichting Zorgveilig. De volgende onderzoeksvragen worden beantwoord:

1. Wat zijn de effecten van de ervaringsgerichte benaderingswijze 'de ParticipatieKliniek' (PK) onder zorgprofessionals ten aanzien van:

a. persoonsgericht werken;

b. basisbehoeften voor zelfbeschikking (autonomie, competenties, verbondenheid);

c. sociaal organisatiekapitaal?

2. Wat is de toegevoegde waarde van een organisatiespecifieke ervaringsgerichte leerinterventie binnen zorgorganisaties op deze indicatoren?

3. Wat zijn de werkzame elementen van de gehanteerde organisatiespecifieke ervaringsgerichte aanpak voor de genoemde indicatoren?

\section{De PK-aanpak}

De PK is een ervaringsgerichte benaderingswijze, waarin zorgprofessionals een tijdelijke rolwisseling als cliënt ervaren. Op basis van deze cliëntbeleving leren ze van en met elkaar hoe ze die ervaringen kunnen omzetten naar de praktijk. De collectieve leertheorie Theory $U$ fungeert als theoretisch fundament en inspiratiebron [8]. Het leerproces dat in de U-beweging wordt doorlopen nodigt mensen uit om actief te participeren. Dat gebeurt door hen te confronteren met hun eigen vooronderstellingen, door zich te verplaatsen in andere perspectieven, door collectief de onzekerheid en handelingsverlegenheid te ervaren die dit met zich meebrengt, en door een context en middelen aan te reiken om deze ervaringen en opgedane leerinzichten toe te passen in de 
beroepspraktijk. In de $\mathrm{PK}$ is dat in vereenvoudigde vorm als volgt gehanteerd:

1. Samen Zien: ervaringsleren in de vorm van een rolwisseling;

2. Samen Delen: delen en leren van elkaars ervaringen en verhalen;

3. Samen Doen: ervaring opdoen met andere - meer persoonsgerichte-manieren van (samen)werken in de praktijk en daarvan leren.

\section{De PK bestaat concreet uit:}

a) Een 24-uurs-event ('de PK'), met aansluitende bijeenkomst in de organisatie ('Clinic')

Zorgprofessionals worden voor 24-uur 'opgenomen' als cliënt in een verzorgingshuis. Binnen dit event is nadrukkelijk aandacht voor het delen van ervaringen. Ook zijn er werkvormen die de transfer naar de praktijk bevorderen. Ongeveer twee maanden daarna vindt een grootschalige bijeenkomst plaats in de organisatie ('Clinic'), met als doel de ervaringen en inzichten verder te delen en verspreiden. Eerder onderzoek onder 619 zorgprofessionals wijst uit dat het event voor $97 \%$ van de deelnemers leidt tot nieuwe inzichten over het vakgebied en voor $87 \%$ aanzet tot meer persoonsgerichte manieren van (samen)werken [18].

b) Een organisatiespecifieke aanpak ('PK-in-Huis') PK-in-Huis faciliteert een collectief leerproces binnen zorgorganisaties, met actieve betrokkenheid van belanghebbenden [19]. Een werkgroep met vertegenwoordigers vanuit het bestuur, de staf, zorgprofessionals en andere belanghebbenden geeft invulling en richting aan het leerproces, en initieert en faciliteert ervaringsgerichte activiteiten naar behoeften binnen de organisatie. De PK-in-Huis aanpak kent drie kernelementen [20]:

1.Aansluiting met de organisatie

PK-in-Huis verbindt lopende initiatieven, ontwikkelingen en perspectieven in de organisatie, met als doel het gezamenlijk onderkennen van het belang van ervaringsleren en het stimuleren van de openheid om ervaringsleren geïntegreerd toe te passen in de organisatie.

2. Integreren van PK-ervaringen in de organisatiepraktijk

Gangbare routines, overlegvormen en bijeenkomsten worden ervaringsgericht ingevuld (werkoverleg, familiebijeenkomsten, cliëntenraadbijeenkomsten, scholing of inwerkprogramma's).

3. Extra PK-impulsen buiten de reguliere activiteiten Buiten de reguliere activiteiten worden grootschalige ervaringsgerichte events georganiseerd, waarin zorgprofessionals en anderen (leidinggevenden, bestuurders, familieleden, mantelzorgers en beleidsmakers) een rolwisseling als cliënt ervaren en daarover in gesprek gaan. Als voorbeeld een 'ontzorgfestival', waarin zorgprofessionals in een carrousel vijf afzonderlijke ervaringen opdoen.

\section{Methode \\ Onderzoeksontwerp}

Gekozen is voor een mixed methods actieonderzoek. Tussentijdse evaluaties zijn gezamenlijk geduid en vormden input voor het vervolg. Inherent aan een collectief leerproces is dat niet alles is te voorzien. Daarom is via open vragen en focusgroepinterviews ruimte gelaten voor onvoorziene effecten. De evaluatie vindt plaats as-treated: groepen zijn vergeleken op basis van wat in de praktijk plaatsvond.

\section{Deelnemers}

De deelnemers zijn zorgprofessionals uit 21 intramurale verpleeghuiszorgorganisaties voor ouderen die om somatische of psychogeriatrische redenen niet meer thuis kunnen wonen. Al deze organisaties bevinden zich in de ontwikkeling naar meer persoonsgerichte zorg. Elk van deze organisaties hanteert daarvoor eigen leer- en ontwikkeltrajecten. Alle hebben gemeen dat ze daar een impuls aan willen geven via ervaringsleren.

In zestien organisaties vond het 24-uurs-PK-event plaats, aangevuld met een eenmalige bijeenkomst in de organisatie ('Clinic'). In vijf organisaties vond aansluitend het organisatiespecifieke 'PK-in-Huis'-traject plaats.

In totaal hebben 904 verzorgenden en verpleegkundigen deelgenomen: 584 (65\%) uit de zestien organisaties waarin het PK-event en de Clinic plaatsvonden, 313 (35\%) uit de vijf organisaties waarin ook een PKin-Huis-traject plaatsvond.

\section{Gegevensverzameling en -verwerking}

Alle deelnemers vulden voorafgaand aan het 24-uursevent een vragenlijst in. De vragen werden beantwoord op een vijfpuntsschaal (1 'helemaal oneens', 5 'helemaal eens'). Gevraagd is naar:

a) De basisbehoeften voor zelfbeschikking:

- autonomie; voorbeelditem: 'Ik voel me vrij mijn werk te doen zoals ik denk dat het goed is';

- competenties; voorbeelditem: 'Ik heb het gevoel dat ik ook de moeilijke taken op mijn werk tot een goed einde kan brengen';

- verbondenheid; voorbeelditem: 'Ik kan met anderen op het werk praten over wat ik echt belangrijk vind'.

- Deze vragen zijn ontleend aan de Work-Related Basic Need Satisfaction Scale (W-BNS) [21]. Van de oorspronkelijke vragenlijst zijn per basisbehoefte twee items gebruikt. 
b) Twee typen sociaal organisatiekapitaal:

- bonding social capital (horizontaal, samenwerking en interacties onder zorgprofessionals); voorbeelditem: 'In ons team heerst een wij-samengevoel';

- linking social capital (verticaal, de samenwerking en interacties tussen leidinggevenden en medewerkers); voorbeelditem: 'Ik voel me gehoord door mijn leidinggevende'.

- Per 'type' zijn twee items van een gevalideerde vragenlijst naar sociaal organisatiekapitaal gebruikt [22].

De nameting vond plaats in juni 2018 en is ingevuld door 165 deelnemers (72 PK-in-Huis, 93 overige organisaties). Het betrof een online vragenlijst. Doordat de nulmeting voorafgaand aan het event plaatsvond en de events in zes maanden tijd zijn uitgevoerd is de periode tussen de nul- en de nameting niet voor iedereen gelijk en varieert deze van vier tot negen maanden.

Naast bovengenoemde vragen werd bij de nameting ook gevraagd naar de mate waarin men veranderingen heeft doorgevoerd:

- Heb je naar aanleiding van de PK veranderingen doorgevoerd in de praktijk? (ja/nee)

- In welke mate heb je naar aanleiding van de PK onderstaande veranderingen doorgevoerd? (1 'helemaal oneens', 5 'helemaal eens')?

c) Eerste-ordeleereffecten (individueel verbeteren):

- andere, meer persoonsgerichte omgang met cliënten qua taal en bejegening;

- meer letten op een prettige woon- of leefomgeving voor cliënten.

d) Tweede-ordeleereffecten (veranderen in samenspraak met anderen):

- ander, meer cliëntgericht teamoverleg;

- andere, meer actieve inbreng in cliëntbesprekingen;

- meer bespreekbaar maken van belangrijke zaken met collega's;

- meer bespreekbaar maken van belangrijke zake met leidinggevende;

- anders, meer cliëntgericht in gesprek met familieleden of mantelzorgers.

Tot slot is gevraagd naar:

e) de mate van aansluiting van en ruimte voor ervaringsleren bij de organisatieontwikkeling en andere initiatieven ( 1 'helemaal oneens, het staat los van elkaar', 5 'helemaal eens, er is een goede aansluiting met andere ontwikkelingen');

f) het feit of medewerkers actief betrokken zijn bij ervaringsgerichte activiteiten in de gangbare gewoonten en bijeenkomsten in de organisatie (ja/nee);

g) het feit of medewerkers actief betrokken zijn bij grootschalige ervaringsgerichte activiteiten die buiten reguliere bijeenkomsten plaatsvonden (ja/nee).

\section{Statistische analyses}

De percentages en gemiddelden van alle variabelen zijn berekend. T-toetsen zijn verricht om te bepalen of er statistische verschillen zijn tussen de PK-in-Huisorganisaties en de andere organisaties.

De antwoorden op de stellingen naar doorgevoerde veranderingen zijn gedichotomiseerd: 'eens' en 'helemaal eens' zijn als groep onderscheiden van de andere antwoorden ('eens noch oneens', 'oneens' en 'helemaal oneens').

Via regressieanalyses is bepaald wat de invloed is van de drie afzonderlijke kernelementen van de organisatiespecifieke aanpak op:

1. de veranderingen die zorgprofessionals in de praktijk hebben doorgevoerd;

2. de psychologische basisbehoeften voor zelfbeschikking en het sociaal organisatiekapitaal.

\section{Kwalitatieve gegevens}

Bij elk van de vijf PK-in-Huis-organisaties heeft één focusgroepinterview plaatsgevonden op bestuurs- en stafniveau (drie tot vijf deelnemers). Hierin zijn het nut en de toepasbaarheid van de PK-benaderingswijze besproken en is nagegaan of en in welke mate de ervaringsgerichte aanpak aanleiding is geweest tot veranderingen op beleidsniveau. In elk van de vijf PK-inHuis-organisaties hebben twee focusgroepbijeenkomsten plaatsgevonden onder zorgprofessionals (vijf tot acht deelnemers). Daarbij is dieper ingegaan op de inzichten die zijn opgedaan dankzij deze vorm van ervaringsleren, de veranderingen die in de praktijk zijn doorgevoerd en de bevorderende of belemmerende factoren daarvoor. Alle interviews zijn uitgeschreven. Overkoepelende inzichten zijn via een membercheck voorgelegd aan de deelnemers van de focusgroepinterviews, die deze hebben aangescherpt en onderschreven.

\section{Resultaten}

In totaal geeft $92 \%$ van de deelnemers aan veranderingen doorgevoerd te hebben in de praktijk (tab. 1). In vergelijking met alleen het 24-uurs-event leidt een organisatiespecifiek vervolg vaker tot 'diepere', tweedeordeleereffecten.

Tabel 2 toont de basisbehoeften van zelfbeschikking en het sociaal organisatiekapitaal op de voor- en de nameting. Voor de totale groep is er geen effect op autonomie, competenties en verbondenheid. Er is een geringe daling in sociaal organisatiekapitaal. Dat geldt voor zowel de horizontale interacties tussen zorgprofessionals onderling $(\mathrm{T}=-4,180, p<0,001)$ als de hiërarchische interacties tussen de leidinggevende en medewerkers $(T=-3,365, p<0,01)$. Uitgesplitst naar de twee onderscheiden groepen (PK-in-Huis en overige) blijkt dat de gevoelens van autonomie en verbondenheid in PK-in-Huis-organisaties een lichte 
Tabel 1 Percentage zorgprofessionals dat aangeeft veranderingen te hebben doorgevoerd in de praktijk

\begin{tabular}{|c|c|c|c|}
\hline & $\begin{array}{l}\text { PK-in-Huis } \\
(n=72)\end{array}$ & $\begin{array}{l}\text { Overige organisaties } \\
(n=93)\end{array}$ & $\begin{array}{l}\text { Totaal } \\
(n=165)\end{array}$ \\
\hline & $\%$ & $\%$ & $\%$ \\
\hline $\begin{array}{l}\text { Heb je naar aanleiding van de PK-veranderingen doorgevoerd in } \\
\text { de praktijk? }\end{array}$ & 94 & 89 & 92 \\
\hline \multicolumn{4}{|l|}{ eerste-ordeleereffecten } \\
\hline $\begin{array}{l}\text { - andere, meer persoonsgerichte omgang met cliënten qua } \\
\text { taal, bejegening, zorg }\end{array}$ & 65 & 70 & 67 \\
\hline $\begin{array}{l}\text { - meer letten op een prettige woon- of leefomgeving voor } \\
\text { cliënten }\end{array}$ & 89 & 79 & 82 \\
\hline \multicolumn{4}{|l|}{ tweede-ordeleereffecten } \\
\hline - ander, meer cliëntgericht teamoverleg & $29^{*}$ & 11 & 19 \\
\hline - andere, meer actieve inbreng in cliëntbesprekingen & 46 & 34 & 39 \\
\hline $\begin{array}{l}\text { - meer bespreekbaar maken van belangrijke zaken met col- } \\
\text { lega's }\end{array}$ & $81^{*}$ & 61 & 70 \\
\hline $\begin{array}{l}\text { - meer bespreekbaar maken van belangrijke zaken met lei- } \\
\text { dinggevende }\end{array}$ & 51 & 44 & 46 \\
\hline $\begin{array}{l}\text { - anders, meer cliëntgericht in gesprek met familieleden of } \\
\text { mantelzorgers }\end{array}$ & $58^{\dagger}$ & 40 & 48 \\
\hline
\end{tabular}

stijging laten zien, terwijl die in de overige organisaties licht dalen. De geconstateerde daling in sociaal organisatiekapitaal blijkt vooral voor te komen in de organisaties waarin geen organisatiespecifiek vervolg plaatsvond. Voor de PK-in-Huis-organisaties blijft het sociaal organisatiekapitaal gelijk.

In de focusgroepinterviews, op bestuursniveau en onder zorgprofessionals, is dit verschil in de sociale werkbeleving aan de orde geweest. Deze leverden twee mogelijke verklaringen op. De daling in sociaal organisatiekapitaal kan een uiting zijn van een algeheel spanningsveld in de zorg, waarin de zorgvragen in aantal en complexiteit toenemen, en waarin personeel schaars is. Het gevolg is dat de samenwerking en interacties tussen mensen onder druk staan. Het is denkbaar dat een organisatiespecifieke aanpak deze negatieve tendens in werkbeleving kan keren. Een andere verklaring is dat mensen die het event hebben meegemaakt graag anders willen werken, terwijl collega's en leidinggevenden daar (nog) niet voor openstaan. Een organisatiespecifiek vervolg leidt mogelijk tot meer gelijkgestemden en daarmee tot een betere beleving van het sociale werkklimaat. Hoewel uit dit onderzoek niet kan worden opgemaakt welke verklaring doorslaggevend is, lijkt de stelling gerechtvaardigd dat het 24-uurs-event vooral tot zijn recht komt in samenhang met een organisatiespecifiek vervolg.

Tabel 3 toont veranderingen die via de open vragen en focusgroepinterviews zijn onderkend.

Tabel 4 toont de regressieanalyses van de drie kernelementen van PK-in-Huis op de veranderingen die zorgprofessionals zeggen te hebben doorgevoerd, de psychologische basisbehoeften voor zelfbeschikking en het sociaal organisatiekapitaal.

Actieve betrokkenheid bij elementen van ervaringsleren blijkt gerelateerd aan een meer persoonsgerichte manier van (samen)werken. De betrokkenheid van medewerkers bij ervaringsgerichte events waaraan zij gezamenlijk met andere belanghebbenden deelnemen stimuleert ook de onderlinge interacties in de praktijk (tijdens cliëntbesprekingen, met leidinggevenden en met familieleden).

\begin{tabular}{|c|c|c|c|c|c|c|c|c|}
\hline & \multirow{7}{*}{\multicolumn{2}{|c|}{ 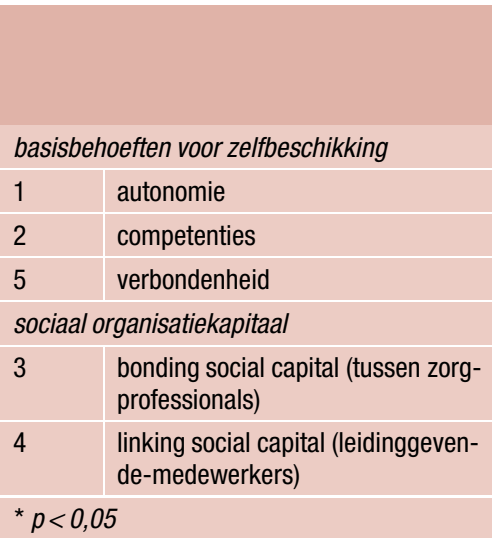 }} & \multicolumn{2}{|c|}{$\begin{array}{l}\text { PK-in-Huis } \\
(n=72)\end{array}$} & \multicolumn{2}{|c|}{$\begin{array}{l}\text { Overige } \\
(n=93)\end{array}$} & \multicolumn{2}{|c|}{$\begin{array}{l}\text { Totaal } \\
(n=165)\end{array}$} \\
\hline & & & \multirow{6}{*}{\begin{tabular}{|l|} 
Voor \\
4,17 \\
4,18 \\
3,72 \\
3,97 \\
3,97 \\
\end{tabular}} & $\mathrm{Na}$ & Voor & $\mathrm{Na}$ & Voor & $\mathrm{Na}$ \\
\hline & \multicolumn{8}{|c|}{ basisbehoeften voor zelfbeschikking } \\
\hline & & & & 4,25 & 4,17 & 4,07 & 4,18 & 4,16 \\
\hline \multirow{6}{*}{$\begin{array}{l}\text { Tabel } 2 \text { Gemiddelden } \\
\text { voor de basisbehoeften } \\
\text { voor zelfbeschikking en het } \\
\text { sociaal organisatiekapitaal, } \\
\text { voor- en nameting (1 'laag', } \\
5 \text { 'hoog') }\end{array}$} & & & & 4,19 & 4,20 & 4,15 & 4,20 & 4,18 \\
\hline & & & & 3,89 & 3,80 & 3,70 & 3,77 & 3,79 \\
\hline & \multicolumn{8}{|c|}{ sociaal organisatiekapitaal } \\
\hline & & & & 3,83 & 4,01 & $3,74^{*}$ & 4,00 & $3,79^{*}$ \\
\hline & & & & 3,86 & 3,88 & $3,63^{*}$ & 3,93 & $3,74^{*}$ \\
\hline & \multicolumn{8}{|c|}{${ }^{*} p<0,05$} \\
\hline
\end{tabular}


Tabel 3 Veranderingen die in de praktijk zijn doorgevoerd, onderkend vanuit de focusgroepinterviews

\begin{tabular}{|c|c|}
\hline Doorgevoerde verandering & Toelichting \\
\hline $\begin{array}{l}\text { - versterking van de erva- } \\
\text { ringskennis }\end{array}$ & $\begin{array}{l}\text { beter inleven in de cliënt, beter begrip voor het gedrag van de cliënt en diens behoefte } \\
\text { aan zorg }\end{array}$ \\
\hline $\begin{array}{l}\text { - verandering van de eigen } \\
\text { leerstrategie door zorgpro- } \\
\text { fessionals }\end{array}$ & $\begin{array}{l}\text { zorgprofessionals nemen zelf initiatief voor ervaringsgerichte activiteiten om daarvan } \\
\text { met elkaar te leren en daardoor te verbeteren }\end{array}$ \\
\hline $\begin{array}{l}\text { - meer leerrendement uit } \\
\text { opleidingen }\end{array}$ & $\begin{array}{l}\text { verwante opleidingen, bijvoorbeeld inhoudelijke kennis over dementie, beklijven beter } \\
\text { door de cliëntervaring }\end{array}$ \\
\hline - beleid tegen het licht & $\begin{array}{l}\text { - herbezinning van het nachtzorgbeleid } \\
\text { - aanpassing van autorisatie voor inkoop van maaltijden } \\
\text { - verbouwing om onrust voor cliënten te beperken } \\
\text { - ervaringsgerichte inwerkprogramma's voor medewerkers en vrijwilligers }\end{array}$ \\
\hline - leren met netwerkpartners & $\begin{array}{l}\text { regionale samenwerking van zorgorganisaties, onderwijsinstellingen en andere net- } \\
\text { werkpartners met betrekking tot ervaringsgericht leren }\end{array}$ \\
\hline
\end{tabular}

Ervaringsgerichte bijeenkomsten hebben geen aantoonbare effecten op de drie basisbehoeften voor zelfbeschikking (autonomie, competenties, verbondenheid). Zelfbeschikking en sociaal organisatiekapitaal zijn vooral gebaat bij een goede aansluiting van ervaringsleren met organisatieontwikkeling en lopende initiatieven.

\section{Beschouwing}

Dit onderzoek beschrijft de effecten van ervaringsleren in de verpleeghuiszorg. Ook is aandacht besteed aan de manier waarop ervaringsleren kan worden verankerd in de organisatie en wat daarvan de toegevoegde waarde is. Bij de ontwikkeling van deze er- varingsgerichte leerinterventie zijn wetenschappelijke inzichten gecombineerd met praktijkervaringen [23]. Dat heeft geleid tot ervaringsgerichte, narratieve en theatrale werkvormen die op diverse niveaus kunnen worden ingezet. De PK kent een positief motiverende stijl. Het gaat om verleiden, prikkelen, ontregelen, spiegelen en voelen. De PK beoogt bewuste eigenzinnigheid te wekken om zo nu en dan 'rebels' te zijn als dat de zorg ten goede komt [24]. Het onderzoek laat het belang zien van ervaringsleren voor de ontwikkeling naar meer persoonsgerichte zorg: 92\% van de deelnemers geeft aan veranderingen in de praktijk te hebben doorgevoerd en $67 \%$ geeft aan cliënten meer persoonsgericht te bejegenen.
Tabel 4 Regressieanalyses van de drie kernelementen van PK-in-Huis op de veranderingen in de praktijk, basisbehoeften voor zelfbeschikking en sociaal organisatiekapitaal ( $\beta$ 's ${ }^{\text {a) }}$

\begin{tabular}{|c|c|c|c|c|}
\hline PK-kernelementen: & $\mathrm{R}^{2}$ & $\begin{array}{l}\text { 1. Aansluiting met } \\
\text { de organisatie }\end{array}$ & $\begin{array}{l}\text { 2. Integreren van erva- } \\
\text { ringsleren in organisatie- } \\
\text { praktijk }\end{array}$ & $\begin{array}{l}\text { 3. Organiseren van } \\
\text { ervaringsgerichte } \\
\text { events }\end{array}$ \\
\hline \multicolumn{5}{|c|}{ doorgevoerde veranderingen in de praktijk } \\
\hline \multicolumn{5}{|l|}{ eerste-ordeveranderingen } \\
\hline $\begin{array}{l}\text { - meer persoonsgerichte cliëntbe- } \\
\text { jegening }\end{array}$ & 0,08 & - & $\beta=+0,17$ & $\beta=+0,16$ \\
\hline $\begin{array}{l}\text { - meer letten op prettige leefomge- } \\
\text { ving }\end{array}$ & 0,12 & - & $\beta=+0,20$ & $\beta=+0,21$ \\
\hline \multicolumn{5}{|l|}{ tweede-ordeveranderingen } \\
\hline - meer cliëntgericht teamoverleg & 0,12 & - & $\beta=+0,16$ & $\beta=+0,25$ \\
\hline $\begin{array}{l}\text { - actievere inbreng in cliëntbespre- } \\
\text { king }\end{array}$ & 0,09 & - & - & $\beta=+0,23$ \\
\hline $\begin{array}{l}\text { - belangrijke zaken meer be- } \\
\text { spreekbaar met collega's }\end{array}$ & 0,08 & - & $\beta=+0,16$ & $\beta=+0,17$ \\
\hline $\begin{array}{l}\text { - belangrijke zaken meer be- } \\
\text { spreekbaar met leiding }\end{array}$ & 0,10 & - & - & $\beta=+0,23$ \\
\hline $\begin{array}{l}\text { - meer cliëntgericht overleg met } \\
\text { familie }\end{array}$ & 0,09 & - & - & $\beta=+0,23$ \\
\hline \multicolumn{5}{|c|}{ psychologische basisbehoeften voor zelfbeschikking } \\
\hline - autonomie & 0,07 & $\beta=+0,24$ & - & - \\
\hline - competenties & 0,02 & - & - & - \\
\hline - verbondenheid & 0,16 & $\beta=+0,41$ & - & - \\
\hline \multicolumn{5}{|l|}{ sociaal organisatiekapitaal } \\
\hline - bonding social capital & 0,05 & $\beta=+0,21$ & - & - \\
\hline - linking social capital & 0,20 & $\beta=+0,44$ & - & $\beta=+0,15$ \\
\hline
\end{tabular}


Een organisatiespecifiek vervolg met actieve betrokkenheid van belanghebbenden blijkt een meerwaarde te hebben $[19,25]$. Het zet aan tot dieper leren (leren in interactie met anderen) en stimuleert (beleidsmatige) veranderingen in de organisatie waar de betrokkenen samen de schouders onder willen zetten. Actieonderzoek als integraal onderdeel van het (interventie)proces bleek hierin een relevante en continue bron van informatie en inspiratie voor het vervolg [26].

Voor het stimuleren van zelfbeschikking of sociaal organisatiekapitaal is het organiseren van louter ervaringsgerichte events niet voldoende. Daarvoor bleek vooral de aansluiting tussen de diverse lopende initiatieven en perspectieven die vanuit de werkgroep tot stand kwam van belang. Meer nog dan het organiseren van ervaringsgerichte events lijkt de gezamenlijke betekenisgeving of sensemaking van belang om zelfleiderschap en sociaal organisatiekapitaal onder zorgprofessionals te stimuleren [27].

Het onderzoek kent een aantal methodologische beperkingen. De bevindingen zijn door de deelnemers zelf gerapporteerd, met mogelijk bias als gevolg. De mate waarin veranderingen zijn doorgevoerd kunnen overschat zijn en deelnemers kunnen sociaal wenselijke antwoorden geven. Gekozen is voor een as-treated evaluatie, waarbij deelnemers zelf aangeven welke PK-onderdelen actief zijn ingezet. Een voordeel is dat de werkzame elementen van de aanpak via regressieanalyses kunnen worden onderzocht. Een nadeel is dat er geen gegevens zijn van zorgorganisaties en zorgprofessionals voor wie in het geheel geen interventie plaatsvond. Er is dus geen controlegroep.

Om de vragenlijst beknopt te houden zijn items uit gevalideerde vragenlijsten gebruikt [21, 22]. Gebruik van de gehele schalen zou meer robuuste uitspraken toelaten, maar daarmee zou de vragenlijst veel langer zijn geworden. Dat was onwenselijk omdat de nulmeting voorafgaand aan het event werd ingevuld en moest aansluiten bij het tempo en de energie ervan.

Dit onderzoek biedt inzicht in de mate waarin zorgprofessionals via ervaringsleren worden gestimuleerd en in staat worden gesteld tot het bieden van meer persoonsgerichte zorg in de praktijk. Om uitspraken over effecten op de langere termijn te kunnen doen is longitudinaal onderzoek nodig. De periode tussen de nul- en de nameting is relatief kort na het event en niet voor iedereen gelijk (vier tot negen maanden na het event). Daar moet in de interpretatie van de bevindingen rekening mee worden gehouden. De gegevens laten het niet toe om antwoord te geven op de vraag of en zo ja in welke mate de effecten uitdoven. Toekomstig longitudinaal onderzoek zal dat moeten uitwijzen.

De PK wordt bezocht door een selecte, zeer gemotiveerde groep zorgprofessionals [23, 28]. Ook de hoge beginwaarde van autonomie, competenties en verbondenheid duiden op een selecte, positief ingestelde groep. De nameting kent bovendien een lage respons. De online vragenlijst werd in de drukke maand juni per mail verstuurd. Navraag in de focusgroepen leerde dat veel van de betrokken zorgprofessionals hun werke-mail weinig gebruiken en in de drukke junimaand misschien nog minder dan gewoonlijk. Al met al zijn de bevindingen gebaseerd op een selecte groep en dus niet zonder meer te generaliseren.

\section{Conclusie}

De ervaringsgerichte benaderingswijze van de ParticipatieKliniek stimuleert zorgprofessionals tot meer persoonsgerichte manieren van (samen)werken in de ouderenzorg. Een organisatiespecifiek ervaringsgericht vervolg blijkt een toegevoegde waarde te hebben. Het leidt tot 'dieper' leren en tot veranderinitiatieven waar betrokkenen samen de schouders onder willen zetten. Voor het bevorderen van zelfbeschikking onder zorgprofessionals en het vergroten van sociaal organisatiekapitaal is het organiseren van ervaringsgerichte events alleen niet voldoende. Daarvoor is de aansluiting tussen de diverse lopende initiatieven en perspectieven en de gezamenlijke betekenisgeving aan ervaringsleren relevanter.

Open Access This article is distributed under the terms of the Creative Commons Attribution 4.0 International License (http://creativecommons.org/licenses/by/4.0/), which permits unrestricted use, distribution, and reproduction in any medium, provided you give appropriate credit to the original author(s) and the source, provide a link to the Creative Commons license, and indicate if changes were made.

\section{Literatuur}

1. Ministerie van VWS. Beleidsagenda. Nederland gezond en wel. Den Haag: Ministerie van VWS; 2019.

2. Baart A. De ontdekking van kwaliteit. Theorie en praktijk van relationeel zorg geven. Amsterdam: SWP Uitgeverij; 2018.

3. Schön DA. The reflective practitioner: how professionals thinkin action. NewYork: Basic Books; 1983.

4. V\&VN Commissie Ethiek. Individuele professionaliteit. Handreiking voor verpleegkundigen en verzorgenden. Utrecht: V\&VN;2012.

5. Vuuren T van, Smit A, Wolswijk A. Daadwerkelijk werk maken van gezamenlijke verantwoordelijkheid voor duurzame inzetbaarheid in de VVT. Waarom nemen werkgevers én werknemers verantwoordelijkheid voor investeren in duurzame inzetbaarheid? Onderzoek in opdracht van de Stichting Arbeidsmarkten Opleidingsbeleid Verpleeg-, Verzorgingshuizen en Thuiszorg (A+O VVT). Heerlen: Loyalis Kennis \& Consult; 2016.

6. Ryan RM, Deci EL. Self-determination theory and the facilitation of intrinsic motivation, social development, and well-being. Am Psychol. 2000;55(1):68-78.

7. Scheppingen AR van, Vroome EMM de, Have CJM ten, ZwetslootGIJM, Mechelen Wvan. Vitality at work and its associations withlifestyle, self-determination, organizational culture, and with employees' performance and sustainable employability. Work. 2015;52(1):45-55. 
8. ScharmerO, TheoryU.leadingfrom thefutureasitemerges: the societal technology of presencing. San Francisco: Berrett-Koehler Publishers; 2009.

9. Fullan M, Langworthy M. A rich seam: how new pedagogies find deep learning. London: Pearson; 2014.

10. Argyris C, Schön D. Organizational learning II: theory, method and practice. Boston: Addison Wesley; 1996.

11. Boonstra JJ. Lopen over water. Over de dynamiek van lerend veranderen in organisaties. Rede uitgesproken bij de aanvaarding van het ambt als hoogleraar Management van veranderingen in organisaties aan de Universiteit van Amsterdam. Amsterdam: Vosiuspers; 2000.

12. NovakJD. Meaningful learning: the essential factor for conceptual change in limited or inappropriate propositional hierarchies leading to empowerment of learners. Sci Educ. 2002;86:548-71.

13. Aukes LC. Personal reflection in medical education. Proefschrift. Groningen: Rijksuniversiteit Groningen; 2008.

14. Vanlaere L, Coucke T, Gastmans C. Experiential learning of empathyin acare-ethicslab. NursEthics. 2010;17(3):325-36

15. Roberts D, Mason J, Williams E, Roberts N, MacPherson R. Promoting empathy through immersive learning. J Nurs Educ Pract. 2016;6:1-9.

16. Cusveller B. Simulatieleren en morele vorming van verpleegkundigen: ethiekonderwijs 3.0. Tijdschr GezondheidszEthiek. 2017;27(1):26-7.

17. Ditzel LM, Hogarth K, Lesa R. Immersive learning in nursing education: results of a study. J Nurs Educ Pract. 2017;7(5):120-30.

18. Scheppingen A van, Bus J, Verhoeven S. De ParticipatieKliniek kantelt en beweegt. Zet een 24-uurs belevingsevent aan tot persoonlijk leiderschap onder verzorgenden en verpleegkundigen? Tijdschr Toegepaste Arbowet. 2017;30(4):139-47.

19. Zouwen T van der. Building an evidence based practical guide to large scale interventions: towards sustainable change with the whole system. Delft: Eburon; 2011.
20. Scheppingen AR van, Have CJM ten, Zwetsloot GIJM, KokG, Mechelen $W$ van. Determining organisation-specific factors for developing health interventions in companies by a Delphi procedure: organisational Mapping. J Health Psychol. 2015;20(12):1509-22.

21. Broeck A van den, Vansteenkiste M, Witte H de, Soenens B, Lens W. Capturing autonomy, competence, and relatedness at work: construction and initial validation of the workrelated basic need satisfaction scale. JOccup Organ Psychol. 2010;83(4):981-1002.

22. KouvonenA, Kivimaki M, Vahtera J, Oksanen T, Elovainio M, Cox T, et al. Psychometric evaluation of a short measure of social capital at work. BMC Public Health. 2006;6:251.

23. V\&VN. De ParticipatieKliniek onderzocht, intern onderzoeksrapport. Utrecht: V\&VN;2017.

24. Bal R, Weggelaar AM, Wallenburg I. Op zoek naar goede leefsystemen. Zorgrebellen en het doen van kwaliteit. Onderzoek i.o.v. het Consortium Kwaliteit van de Nederlandse Federatie van Universitair Medische Centra en Zorg Instituut Nederland. Rotterdam: Erasmus Universiteit Rotterdam;2018.

25. Scheppingen AR van, Vroome EMM de, Have CJM ten, Bos AH, Zwetsloot GIJM, Mechelen W van. Inducing ahealth-promoting change process within an organization: the effectiveness of a large-scale intervention on social capital, openness, and autonomous motivation toward health. JOccup Environ Med. 2014;56(11):1128-36.

26. Scheppingen A van, Bos E. Het evalueren van de U: leerprocessen in organisaties. Casusbeschrijving TNO. In: de Haan E, Berends E, redactie. Organisatieontwikkeling met Theory U. Amsterdam: Boom Nelissen; 2012. pag. 187-96.

27. Weick K, Sutcliffe KM, Obstfeld D. Organizing and the process of sensemaking. Organ Sci. 2005;16(4):409-21.

28. V\&VN. DeParticipatieKliniekbeweegtverder,intern onderzoeksrapport. Utrecht: V\&VN;2018. 